Rio de Janeiro. Ano 15. Volume 22. Número 3. Setembro a Dezembro de 2021

Periódico Quadrimestral da Pós-Graduação Stricto Sensu em Direito Processual da UERJ

Patrono: José Carlos Barbosa Moreira (in mem.). ISSN 1982-7636. pp. 01-15 www.redp.uerj.br

\title{
ENVISAGING AND ENFORCING INDIVIDUAL, AGGREGATED, \\ COLLECTIVE, DIFFUSE, AND GLOBAL RIGHTS RELATING TO CLIMATE \\ CHANGE, THE GREENHOUSE EFFECT, AND THE ENVIRONMENT ${ }^{1}$ \\ VISIONANDO E IMPLEMENTANDO OS DIREITOS INDIVIDUAIS, AGREGADOS, COLETIVOS, DIFUSOS E GLOBAIS RELACIONADOS ÀS MUDANCAS CLIMÁTICAS, AO EFEITO ESTUFA E AO MEIO AMBIENTE
}

Ángel R. Oquendo George J. and Helen M. England Professor of Law, University of Connecticut; Fulbright Distinguished Chair in Legal Theory, Catholic University of Rio de Janeiro; CAPES Visiting Professor, State University of Rio de Janeiro; DAAD Visiting Professor, Free University of Berlin. Ph.D., M.A. (Philosophy), A.B. (Economics and Philosophy), Harvard University; J.D., Yale Law School. The author presented this paper, as his own ruminations during the luncheon while the audience digested, at the annual symposium of the Connecticut Journal of International Law on Paris, Policy, and The Grid: The Future of Transnational Energy Policy. Along with some organizers of and the participants at the event, Emily Byrnes, Chris Hyde, and Claudia Schubert invaluably contributed to the development of his ideas. Incidentally, he undertook the translation of the quoted non-English-language materials himself and vouches for its accuracy. Connecticut, USA. Email: oquendo@zedat.fu-berlin.de

\begin{abstract}
The 2015 Paris Agreement, complementing the United Nations Framework Convention on Climate Change, showcases an impressive consensus on climatological rhetoric. Thereby, it will contribute certainly neither to achieving its overall objectives on temperature nor to redressing any of the resulting "loss [or] damage" yet possibly to
\end{abstract}

\footnotetext{
${ }^{1}$ Artigo recebido em 29/06/2021, sob dispensa de revisão.
} 
Revista Eletrônica de Direito Processual - REDP.

Rio de Janeiro. Ano 15. Volume 22. Número 3. Setembro a Dezembro de 2021

Periódico Quadrimestral da Pós-Graduação Stricto Sensu em Direito Processual da UERJ

Patrono: José Carlos Barbosa Moreira (in mem.). ISSN 1982-7636. pp. 01-15

www.redp.uerj.br

continuing the worldwide dialogue on the environment or on ecological entitlements. This paper will dissect and categorize these. It will conclude that the framers essentially kept the conversation going, nationally and internationally, encouraging the establishment, the adjudicatory branch, and the public to resume the conceptual or practical advancement on the topic.

KEYWORDS: Aggregated Rights; Bolivia; Citizen Suits; Class Actions; Climate Change; Collective Rights; Constitution; Diffuse Interests; Ecology; Ecuador; Environment; Greenhouse Effect; Human Rights; Individual Rights; India; Injunctions; Inter-American Court of Human Rights; Mother Earth; New Zealand; Pachamama; Popular Suits; Public Interest; Real Party in Interest.

RESUMO: O acordo de Paris de 2015, complementando a Convenção-Quadro das Nações Unidas sobre a Mudança do Clima, apresenta um impressionante consenso na retórica climatológica. Desse modo, certamente não contribuirá para atingir seus objetivos gerais sobre temperatura, nem para corrigir qualquer "perda [ou] dano" resultante; mas, ainda assim, possivelmente contribuirá para a continuidade do diálogo mundial sobre o meio ambiente ou sobre direitos ecológicos. Este artigo tem o objetivo de dissecar e categorizar estes. Será concluído que os formuladores essencialmente mantiveram a conversa em andamento, nacional e internacionalmente, encorajando as instituições, o poder judiciário e o público a retomarem o avanço conceitual ou prático sobre o tema.

PALAVRAS-CHAVE: Direitos agregados; Bolívia; Demandas cidadãs; Ações coletivas; Mudanças climáticas; Direitos coletivos; Constituição; Interesses difusos; Ecologia; Equador; Meio ambiente; Efeito estufa; Direitos humanos; Direitos individuais; Índia; Injunções; Corte Interamericana de Direitos Humanos; Mãe Terra; Nova Zelândia; Pachamama; Ações populares; Interesse público; Parte genuinamente interessada. 
"I've tried to express the terrible human passions with the red and the green. ... Everywhere it's a battle and an antithesis of the most different greens and reds. ..." Vincent van Gogh, Letter to Theo (676) ${ }^{2}$ Arles, September 8, 1888.

The 2015 Paris Agreement, complementing the United Nations Framework Convention on Climate Change, showcases an impressive consensus on climatological rhetoric. ${ }^{3}$ Thereby, it will contribute certainly neither to achieving its overall objectives on temperature ${ }^{4}$ nor to redressing any of the resulting "loss [or] damage" 5 yet possibly to continuing the worldwide dialogue on the environment or on ecological entitlements. This paper will dissect and categorize these. It will conclude that the framers essentially kept the conversation going, nationally and internationally encouraging the establishment, the adjudicatory branch, and the public to resume the conceptual or practical advancement on the topic.

Individualized rights are the most basic item in this categorical scheme. They support claims that someone asserts against somebody else. For instance, $P$ may, under usual circumstances, rightfully insist on her individual entitlements or on indemnification when she confronts a personalized infliction as a consequence of $D$ 's ecologically harmful negligence or maliciousness.

Her allegations may center on a supposed breach of her guaranties as a landowner. Alternatively, she may allege an encroachment upon her environmental entitlements, particularly if her land forgoes none of its market valuation or perceptible beauty. In the nomenclature of Judy Thomson, such safeguards might qualify as "cluster-rights" to the extent that they cluster or encompass other interrelated ones. ${ }^{6}$

\footnotetext{
${ }^{2}$ Letter (676) from Vincent van Gogh to (his brother) Theo van Gogh (Sept. 8, 1888) (on file with author), available at <http://vangoghletters.org/vg/letters/let676/letter.html>.

${ }^{3}$ See Paris Agreement to the United Nations Framework Convention on Climate Change, Dec. 12, 2015, 27 U.N.T.S. 7.d [hereinafter Paris Agreement].

${ }^{4}$ See id. art. 2(1)(a) ("This Agreement ... aims to strengthen the global response to the threat of climate change ... by: Holding the increase in the global average temperature to well below $2^{\circ} \mathrm{C}$ above pre-industrial levels and pursuing efforts to limit the temperature increase to $1.5^{\circ} \mathrm{C}$ above pre-industrial levels ....").

${ }^{5}$ See id. art. 8(1) ("Parties recognize the importance of averting, minimizing and addressing loss and damage associated with the adverse effects of climate change ....").

${ }^{6}$ JUdiTH JARVIS THOMSON, THE REALM OF Rights 55 (1990) ("Let us call rights that contain other rights 'cluster-rights'.”).
} 
Revista Eletrônica de Direito Processual - REDP.

Rio de Janeiro. Ano 15. Volume 22. Número 3. Setembro a Dezembro de 2021

Periódico Quadrimestral da Pós-Graduação Stricto Sensu em Direito Processual da UERJ

Patrono: José Carlos Barbosa Moreira (in mem.). ISSN 1982-7636. pp. 01-15

www.redp.uerj.br

A pair of plaintiffs may combine their corresponding contentions in a single complaint if they can show sufficient legal or factual commonality to justify the combination. ${ }^{7}$ The latter does not deprive the protections in question of their individualized character. For example, $P 1$ and $P 2$ may articulate their averments together and have their guaranties validated in one fell swoop, whenever the defendant injures both of them at once through her negligent or malicious conduct. ${ }^{8}$ They should receive compensation commensurate with what they are individually entitled to.

As the cohort of institutors increases, the denomination 'aggregated singular rights' might become appropriate. Still, the numerous entitlements generally subsist as individual and amenable to apportionment. Graphically, when a substantial set of proprietors sues a construction conglomerate for encroaching upon their proprietorial prerogatives, each one of them usually advances an assertion associated with the particularized detriment that she has experienced. ${ }^{9}$

Such individually held liberties, which allow decoupling despite their commingling, stand in sharp relief against communal ones, which manifest themselves as basically indivisible and concern society as a unit, or a sizeable community. This ampler category comprises generalized guaranties that have attained national or multinational prominence, like that to ecological wholesomeness. ${ }^{10}$ These freedoms have developed more recently than individual ones. ${ }^{11}$ Besides, they often operate as positive entitlements, which compel the government (or private parties) to engage positively in, rather than to refrain negatively from, certain comportment. ${ }^{12}$

\footnotetext{
${ }^{7}$ See, e.g., FED. R. CIV. P. 20(a)(1) ("Persons may join in one action as plaintiffs if: (A) they assert any right to relief jointly, severally, or in the alternative with respect to or arising out of the same transaction, occurrence, or series of transactions or occurrences; and (B) any question of law or fact common to all plaintiffs will arise in the action.").

${ }^{8}$ See, e.g., United States v. Olson, 546 U.S. 43, 45 (2005) ("In this case, two injured mine workers (and a spouse) have sued the United States claiming that the negligence of federal mine inspectors helped bring about a serious accident at an Arizona mine.").

${ }^{9}$ See, e.g., Baatz v. Columbia Gas Transmission, LLC, 814 F.3d 785, 788 (6th Cir. 2016) (“'On December 21, 2012, a group of landowners brought a class action against Columbia in the Southern District of Ohio for [storing natural gas nearby].").

${ }^{10}$ See, e.g., African CHARTER On HUMAN AND PeOPles' Rights (Banjul Charter) art. 24 (1981) (“Right to a General Satisfactory Environment"), adopted June 27, 1981, O.A.U. Doc. CAB/LEG/67/3 rev. 5, 21 I.L.M. 58.

${ }^{11}$ See, e.g. , ÁNGEL R. OQUENDO, LATIN AMERICAN LAW 382 (2017) (hereinafter "OQUENDO, LATIN AMERICAN LAW (2017)") ("Since the attainment of independence in the nineteenth century, constitutions in Latin America have guaranteed negative rights. . . Latin American nations have been incorporating positive rights into their constitutional charters since the beginning of the twentieth century.").

${ }^{12}$ See, e.g., Org. of Am. States (OAS), Additional Protocol to the American Convention on Human Rights in the Area of Economic, Social, and Cultural Rights, "Protocol of San Salvador," art. 11, Nov. 17, 1988, O.A.S.
} 
Revista Eletrônica de Direito Processual - REDP.

Rio de Janeiro. Ano 15. Volume 22. Número 3. Setembro a Dezembro de 2021

Periódico Quadrimestral da Pós-Graduação Stricto Sensu em Direito Processual da UERJ

Patrono: José Carlos Barbosa Moreira (in mem.). ISSN 1982-7636. pp. 01-15

www.redp.uerj.br

Rights attributed indivisibly to several beneficiaries have likely populated regulatory regimens from time immemorial. When a couple of farmers owns a tract of acreage, they normally possess a relatively undividable guaranty regarding it. In parallel, rights ascribed to society at large have chalked up an extremely extended history. Illustratively, the Roman actio popularis enabled ordinary folk to effect the entitlements of the entire citizenry. ${ }^{13}$ The novelty of the contemporary cause of this genre consists in its broad as opposed to narrow availability, in its widespread deployment, and in its focus on modern preoccupations, such as ecology. ${ }^{14}$ The U.S. citizen suit or the civil-law prosecution on so-denominated "diffuse interests" provides a case in point. ${ }^{15}$

For purposes of illustration, one may think of a commercial enterprise that neglects ecological regulations and compromises the welfare of the immediate vicinity. The neighbors who as a result undergo individualized injuries might join their pleas and press for conjoint satisfaction. In addition to this joinder of individual postulations, the surrounding neighborhood might purport to uphold its guaranty to an ecologically sound space or request an equitable order commanding the entrepreneurs to abide by the relevant rules.

The vicinity's societal right transcends any personal one that the neighboring residents might wield. Pertinently, it cannot be apportioned (or divided) among them in a straightforward fashion. An injunction issued against the responsible representatives on account of this commitment benefits the group yet no person in particular.

In fact, an infringement would occur in this scenario irrespective of whether the residences had environmentally depreciated, so to speak. After all, the population as a totality has itself suffered a separate wrong-beyond that that its constituents have had to stomach individually — reflected in the total diminution in quality of living. The individual entitlements link to, while distinctly differentiating themselves from, communal ones.

\footnotetext{
T.S. No. 69, 1144 U.N.T.S. 123 ("The States Parties shall promote the protection, preservation, and improvement of the environment."); see also AFRICAN CHARTER, supra note 10, art. 16(2) ("State Parties to the present Charter shall take the necessary measures to protect the health of their people and to ensure that they receive medical attention when they are sick.").

${ }^{13}$ See DIG. 47.23.1-8 ("De popularibus actionibus").

${ }^{14}$ See, e.g.., Ángel R. Oquendo, Justice for All: Certifying Global Class Actions, 16 WASH. U. GLOBAL STUD. L. REV. 71, 114-15 (2017) [hereinafter "Oquendo, Justice for All (2017)"] ("In the nineteenth century, .. . Latin American Civil Codes . . . codified . . p popular actions . . . for very specific purposes .....") ("Since the 1990s, Latin America . . . has embraced ... wide-ranging public-law actions for the enforcement of diffuse rights."). ${ }^{15}$ See id., at 121 (Diffuse-rights "suits bear a resemblance to . . citizen suits . . . in that they turn on a genuinely collective assertion.”). See generally OQUENDO, LATIN AMERICAN LAW (2017), supra note 11, at 857-929.
} 
Revista Eletrônica de Direito Processual - REDP.

Rio de Janeiro. Ano 15. Volume 22. Número 3. Setembro a Dezembro de 2021

Periódico Quadrimestral da Pós-Graduação Stricto Sensu em Direito Processual da UERJ

Patrono: José Carlos Barbosa Moreira (in mem.). ISSN 1982-7636. pp. 01-15

www.redp.uerj.br

Though both such guaranties may be fulfilled "collectively," a duo of elementary dissimilarities demarcates the agglomerated individualized from the socialized sort. To begin with, those of the former species are readily divisible, whereas the those of the latter are not. Furthermore, the two diverge in their range of application: typically, grouped individual rights themselves attach to a circumscribed yet potentially vast contingent of holders, while their opposite numbers pertain to the polity in its entirety.

In light of their divisibility, such aggregable singular liberties permit either individualized or collectivized effectuation by the possessor itself or a stand-in, respectively. In opposition, their mutual counterparts necessitate joint vindication by means of representation. The members of the larger society could not effectuate their "part" because they may not partition the entitlement itself. Whoever represents them must wholly vindicate it in the name of their ensemble, which looms behind as the real party in interest.

The officialdom performs a primordial part in the defense of these meta-individual freedoms. ${ }^{16}$ It accordingly substantiates them in contradistinction to its own contractual, proprietary, or pecuniary rights. ${ }^{17}$ Exemplifying the dichotomy, the authorities may stake, on the one hand, 'publicly' a claim against a manufacturing company for poisoning a civic recreational park and, on the other, 'privately' an assertion for reparation against the business when it negligently contaminates a governmental plot. In the first pursuit, the leadership enforces entitlements that accrue to the benefit of the populace as a whole. In the second, it implements those that it bears in itself as a juridically configured entity.

Consequently, the sovereign predominates in this enforcement effort. Nevertheless, scores of jurisdictions in the Western Hemisphere have started empowering individuals and organizations to venture a comparable representative role. ${ }^{18}$ In the United States, suitors have

\footnotetext{
${ }^{16}$ See, e.g., Alaska Sport Fishing Ass'n v. Exxon Corp., 34 F.3d 769, 773 (9th Cir. 1994) (per curiam) ("State governments may act in their parens patriae capacity as representatives for all their citizens in a suit to recover damages for injury to a sovereign interest. . . . There is a presumption that the state will adequately represent the position of its citizens.").

17 See, e.g., Alfred L. Snapp \& Son, Inc., v. Puerto Rico ex rel. Barez, 458 U.S. 592, 602 (1982) ("Quasisovereign interests stand apart . . : They are not sovereign interests, proprietary interests, or private interests pursued by the State as a nominal party. They consist of a set of interests that the State has in the wellbeing of its populace.").

18 See generally Oquendo, Justice for All (2017), supra note 14, at 113 (In the last three decades, Latin American "diffuse-rights suits [and, since the 1960s and 1970s, respectively,] Rule 23(b)(2) actions and citizen suits [in the United States] have developed dramatically. . . . They usually entitle any person, without a showing of individual injury, to litigate on behalf of society as a whole or a certain community for injunctive relief and frequently damages, in order to enforce diffuse or societal entitlements, such as those pertaining to the environment or collective cultural goods.").
} 
Revista Eletrônica de Direito Processual - REDP.

Rio de Janeiro. Ano 15. Volume 22. Número 3. Setembro a Dezembro de 2021

Periódico Quadrimestral da Pós-Graduação Stricto Sensu em Direito Processual da UERJ

Patrono: José Carlos Barbosa Moreira (in mem.). ISSN 1982-7636. pp. 01-15

www.redp.uerj.br

long prosecuted class actions and more lately popular suits. ${ }^{19}$ In Continental Europe and

Latin America, the notion of diffusion has contextually emerged to extricate these guaranties

from other ones that anyone may actualize, namely, personalized ones. ${ }^{20}$

At this juncture, the analysis could climb up a step in the spectrum of generality. It could contemplate rights attributable not to a nationality but to all of humanity, against which somebody might perpetrate ecological outrages or crimes. Such a humanitarian entitlement would similarly present itself as monolithic and affirmative while contrasting with an agglomeration of individualized ones. It would call for realization by a public or private prosecutor in transnational tribunals, or in their domestically invested peers with universal jurisdictional reach. Such options could save the situation when nationally or transnationally installed regimes disregard or defy this guaranty. ${ }^{21}$

Newly, the Inter-American judicial forum for human rights has been pondering along these lines. It has embraced ecologically envisaged entitlements that stretch beyond domestic boundaries with such formulations: "To ... guarantee the right to life or to safety of any subject within their purview," administrations must shoulder "a duty to prevent extensive environmental" blight "within and without their territory,"22 as well as "to cooperate with each other in good faith to secure the environment against significant harm."23

The greenhouse effect seems to push in exactly these directions. It obviously has ramifications and roots that cross politically delimited frontiers. Nonetheless, one might feel reluctant to embark upon a guaranties-based response. ${ }^{24}$ One might prefer instead to respond by way of policies.

\footnotetext{
${ }^{19}$ See id.

${ }^{20}$ See id.

${ }^{21}$ See, e.g., Michael D. Shear, Trump Abandoning Global Climate Accord, N.Y. TIMES, June 2, 2017, at A1 ("Mr. Trump's decision to abandon the agreement for environmental action signed by 195 nations is a remarkable rebuke to heads of state, climate activists, corporate executives and members of the president's own staff, who all failed to change his mind with an intense, last-minute lobbying blitz.").

${ }^{22}$ Environment and Human Rights (Arts. 4.1, 5.1, 1.1, and 2 American Convention on Human Rights), Advisory Opinion OC-23/17, Inter-Am. Ct. H.R., II 244(5) ("Con el propósito de respetar y garantizar los derechos a la vida e integridad de las personas bajo su jurisdicción, los Estados tienen la obligación de prevenir daños ambientales significativos, dentro o fuera de su territorio . . . .") (hereinafter Environment and Human Rights Opinion, Inter-Am. Ct. H.R.).

${ }^{23}$ Id. II 244(7) (“[L]os Estados tienen la obligación de cooperar, de buena fe, para la protección contra daños transfronterizos significativos al medio ambiente.").

${ }^{24}$ Bernard Williams, Human Rights: The Challenge of Relativism, Lecture at the Raymond \& Beverly Sackler Distinguished Lecture Series 2 (Apr. 23, 1997) (on file with the author) ("Declarations of human rights standardly proclaim [so-called positive] rights . . . , but there is a problem with them. . . The problem is: against whom is this [kind of] right held? Who violates it if it is not observed? ... I think that it may be unfortunate that [these] declarations ... have, though for understandable reasons, included supposed rights of this kind.").
} 
Revista Eletrônica de Direito Processual - REDP.

Rio de Janeiro. Ano 15. Volume 22. Número 3. Setembro a Dezembro de 2021

Periódico Quadrimestral da Pós-Graduação Stricto Sensu em Direito Processual da UERJ

Patrono: José Carlos Barbosa Moreira (in mem.). ISSN 1982-7636. pp. 01-15

www.redp.uerj.br

Climatic conservation may appear to fit the bill insofar as it comes across as teleological, gradational, relative to specific subgroups, and requiring balancing against competing goals. ${ }^{25}$ In this sense, however, it does not distinguish itself from the promotion of employment, the preservation of salubriousness, or the achievement of self-determination and may equally admit an alternative approach resting on deontologically principled entitlements, supranational or national. ${ }^{26}$ Engagement in this domain might thus gain in visibility and prestige. Moreover, it might ultimately unfold on the basis of principles and adjudicative actualization, rather than values and official discretion. ${ }^{27}$

On first impression, the Parisian pact itself seems to focus principally on "policy," utilizing the noun repeatedly throughout. ${ }^{28}$ Of course, it concomitantly refers to seemingly collateral impacts on a plethora of guaranties. In acknowledging that the atmosphere's thermometric transformation remains "a common concern of humankind," the text specifically commits the signatories, "when" tackling this phenomenon, to "promote," considering "their respective obligations" on, [1] "human rights, ... [2] health," [3] the safekeeping of "indigenous" or other localities, "migrants, children," or anybody with disabilities or vulnerabilities, and [4] rightful "development, or [5] gender equality, [6] empowerment of women and [7] intergenerational equity." 29

Upon deeper inspection, though, the instrument actually appears to be insinuating an ecological entitlement that intricately intertwines with the rest. At base, it might be intimating such intertwinement. In the passage quoted earlier, the Inter-American judges themselves analogously interconnected a series of guaranties, maybe mirroring the petition lodged before them and minding the want of an explicit commitment to ecology in the core

\footnotetext{
${ }^{25}$ See generally JÜRGEN HABERMAS, FAKTIZITÄT UND GELTUNG: BEITRÄGE ZUR DISKURSTHEORIE DES RECHTS UND DES DEMOKRATISCHEN RECHTSSTAATS 311 (1992) ("Norms and values differ in that they respectively refer to obligatory and teleological action, press validity claims with a binary and a gradational coding, bind absolutely and relatively, and must satisfy criteria of interrelation within [normative and eval-uative] systems.") ("Normen und Werte unterscheiden sich also erstens durch ihre Bezüge zu obligatorischem bzw. teleologischem Handeln; zweitens durch die binäre bzw. graduelle Kodierung ihres Geltungsanspruchs; drittens durch ihre absolute bzw. relative Verbindlichkeit und viertens durch die Kriterien, denen der Zusammenhang von Norm- bzw. Wertsystemen genügen muß.”).

${ }^{26}$ See generally id. at 38. ("On ... positive entitlements, [t] he government does not have a vague and wideranging obligation. . . . Instead, it must . . . demonstrate an earnest engagement on the right.”).

${ }^{27}$ See generally $i d$. at 44, 72. ("[A] right essentially embodies a principle or a norm. ... When public officials flout the principle underlying a given entitlement, they should almost ineludibly endure reproof and sanction.") ("At any rate, a court should strictly scrutinize and, thereupon, severely sanction the authorities if they trample upon the principle underlying a particular entitlement.").

${ }^{28}$ See Paris Agreement, supra note 3, arts. 5(2), 7(5), 7(7)(a),7(9), 7(9)(d), 11(4).

${ }^{29}$ Id. pmbl.
} 
Revista Eletrônica de Direito Processual - REDP.

Rio de Janeiro. Ano 15. Volume 22. Número 3. Setembro a Dezembro de 2021

Periódico Quadrimestral da Pós-Graduação Stricto Sensu em Direito Processual da UERJ

Patrono: José Carlos Barbosa Moreira (in mem.). ISSN 1982-7636. pp. 01-15

www.redp.uerj.br

compact within their competence. They further affirmed that "environmental [impairment] can impinge upon . . . all . . rights, [whose] full enjoyment . . rides on" an environmentally

salubrious setting, ${ }^{30}$ and elaborated on this interconnection:

The [entitlement] to a healthy environment has been understood as having both individual and collective connotations. [As to these], it amounts to a boon to future plus present generations. This [protection displays] an individualized dimension to boot, since its violation can have direct or indirect repercussions on people due to its connection with [sundry] rights, like that to healthiness, to personal security, or to life. ${ }^{31}$

Surely, the examined entitlement branches out into others as it applies individually and jointly. The collective may as much as its membership face an impingement upon its sanitary, vital, or related rights.

Notwithstanding, someone might object to instrumentalizations of this guaranty. Concretely, she might repudiate its apparent subordination, if not to others of its kind, then to homo sapiens more broadly. Such an anthropocentric viewpoint would indeed entail shielding biotic treasures solely to the degree that they profit civilization.

In 1972, Justice William Douglas memorably proposed an iconoclastic take while dissenting in Sierra Club v. Morton. "I2 "Inanimate objects," he recalled, "sometimes" feature as "parties" in adjudication. ${ }^{33} \mathrm{He}$ identified "the problem" as assuring them a spokesperson prior to their destruction. ${ }^{34}$ His dissent proclaims that their "voice . . . should not be stilled." 35 It cautions that the "public interest" casts "so many differing shades of meaning as to be quite meaningless on the environmental front." ${ }^{36}$ With a trace of anthropocentricity in spite of himself, the dissenter urged that "before ... priceless bits of Americana (such as a valley, an alpine meadow, [or] a river ...) [were] forever lost or [were] so transformed as to be reduced to the eventual rubble of our urban environment, ... the [extant] beneficiaries of

\footnotetext{
${ }^{30}$ See Environment and Human Rights Opinion, Inter-Am. Ct. H.R., supra note 22, II 64 (“Ahora bien, además del derecho a un medio ambiente sano, como se mencionó previamente, los daños ambientales pueden afectar todos los derechos humanos, en el sentido de que el pleno disfrute de todos los derechos humanos depende de un medio propicio.").

${ }^{31}$ See id., If 59 ("El derecho humano a un medio ambiente sano se ha entendido como un derecho con connotaciones tanto individuales como colectivas. En su dimensión colectiva, el derecho a un medio ambiente sano constituye un interés universal, que se debe tanto a las generaciones presentes y futuras. Ahora bien, el derecho al medio ambiente sano también tiene una dimensión individual, en la medida en que su vulneración puede tener repercusiones directas o indirectas sobre las personas debido a su conexidad con otros derechos, tales como el derecho a la salud, la integridad personal o la vida, entre otros.").

${ }^{32}$ Sierra Club v. Morton, 405 U.S. 727, 741 (1972) (Douglas, J., dissenting).

${ }^{33}$ Id. at 742 .

${ }^{34} I d$. at 745 .

${ }^{35} \mathrm{Id}$. at 749 .

${ }^{36} I d$. at 745 .
} 
Revista Eletrônica de Direito Processual - REDP.

Rio de Janeiro. Ano 15. Volume 22. Número 3. Setembro a Dezembro de 2021

Periódico Quadrimestral da Pós-Graduação Stricto Sensu em Direito Processual da UERJ

Patrono: José Carlos Barbosa Moreira (in mem.). ISSN 1982-7636. pp. 01-15

www.redp.uerj.br

these environmental wonders should be heard." ${ }^{37}$ These words evoke a substantive and procedural guaranty for the animal, vegetable, and mineral kingdom.

Over three decades later, Ecuador's 2008 Constitution, opening (like its 2009 Bolivian analogue) with a celebration of the Andean aboriginal global goddess, "to which we belong as a" crucial "component of our existence," 38 enshrines such a liberty in its Article 71: "[The originally celebrated] Pachamama, where life reproduces and realizes itself, boasts a right to an integral respect" of her existential dominion "and to the maintenance and regeneration of her vital cycles, her structure, and her evolutionary functions or processes." 39 The immediately ensuing provision separates this type of freedom of hers from that retained by earthlings in regard to their personalized or social ecological assets: "[She] enjoys an entitlement to restoration, which shall transpire independently" of the responsibility of the republic conjointly with "natural or juridical persons to indemnify individuals or collectivities that depend" on the biological areas affected. ${ }^{40}$

In 2015, the country's foremost constitutional adjudicators explained that the enshrinement of the "rights" of the conjured deity "constitute[d] one of the major innovations" of the charter, along with the "recognition" of her as an "entitled" personality, "in contrast to the traditional paradigm, which deems [her] a piece of property [or] a mere source of . . resources." 41 They observed a tendency toward "a biocentric relation between [her] and society," inasmuch as the governance document conceives her as a "living" individuality or "procreator" and "grounds" the veneration "owed [her] by human beings on an appreciation of [her] as a holder" of guaranties, "over and above [her] utility." 42 Despite

\footnotetext{
${ }^{37}$ Id. at 750 .

${ }^{38}$ CONST. pmbl. (Ecuador) (2008) ("Celebrando a la naturaleza, la Pacha Mama, de la que somos parte y que es vital para nuestra existencia"). $C f$. CONST. pmbl. (Bol.) (2009) ("Obeying the command of our peoples, with the strength of our Pachamama and with thanks to God, we found Bolivia anew.") ("Cumpliendo el mandato de nuestros pueblos, con la fortaleza de nuestra Pachamama y gracias a Dios, refundamos Bolivia.").

${ }^{39}$ CONST. art. 71 (Ecuador) (2008) ("La naturaleza o Pacha Mama, donde se reproduce y realiza la vida, tiene derecho a que se respete integralmente su existencia y el mantenimiento y regeneración de sus ciclos vitales, estructura, funciones y procesos evolutivos.”).

${ }^{40}$ Id. art. 72 ("La naturaleza tiene derecho a la restauración. Esta restauración será independiente de la obligación que tienen el Estado y las personas naturales o jurídicas de Indemnizar a los individuos y colectivos que dependan de los sistemas naturales afectados.").

${ }^{41}$ Corte Constitucional [Ct. Const.] del Ecuador, July 9, 2015, Sentencia No. 218-15-SEP-CC 9 ("En este sentido, es preciso señalar que los derechos de la naturaleza — pacha mama - constituyen una de las mayores novedades de la Constitución ecuatoriana vigente, al reconocer a la naturaleza como sujeto de derechos, al contrario del paradigma tradicional que la considera como objeto de propiedad y mera fuente de recursos naturales.").

${ }^{42} I d$. at 10 ("Ahora bien, es evidente que las Constitución ecuatoriana tiende a una perspectiva biocéntrica de relación 'naturaleza-sociedad' en la medida en que reconoce a la naturaleza como ser vivo y como dadora de
} 
Revista Eletrônica de Direito Processual - REDP.

Rio de Janeiro. Ano 15. Volume 22. Número 3. Setembro a Dezembro de 2021

Periódico Quadrimestral da Pós-Graduação Stricto Sensu em Direito Processual da UERJ

Patrono: José Carlos Barbosa Moreira (in mem.). ISSN 1982-7636. pp. 01-15

www.redp.uerj.br

lacking clear textual cover in the Constitution within its competency, the Colombian constitutional bench has correspondingly assumed an "eco-centric perspective" to accomplish "greater justice for nature" and espouse "biocultural" entitlements. ${ }^{43}$ It has mandated this accomplishment "beyond" the humanly civilized "realm" and the acceptance of the faunal, floral, and elemental universe as "a subject of rights." 44

Bolivia's Law 71 of 2010 pursues an identical aim in an extra pantheistic spirit. ${ }^{45}$ It consecrates the guaranties of the maternal planet, obligating "society to . . respect ... them." 46 The statute spells out the terms of interaction of these entitlements with others. First: "Society's interest, in [this] context . . , shall prevail in all spheres of human activity and over any acquired right." 47 Secondly: "All Bolivians, as members" of the constellation of creatures within "Mother Earth, shall exercise [her guaranties] compatibly with their own," whether "individual" or "collective."48 Finally: "The exercise of entitlements individually shall be limited by that collectively within her life systems. Conflicts shall be resolved so as not to alter the functionality of these systemic units irreversibly."49

Comparably, the High Court of Uttarakhand at Nainital in India declared "Rivers and Lakes" inherently warranted from being "polluted." "Forests, [other] Water Bodies, Air, Glaciers [or] Springs," sported "a right to exist, persist, maintain, sustain and regenerate their own . . . ecology." ${ }^{51}$ The justices enunciated that they

vida y por tanto, fundamenta el respeto que le deben los seres humanos en su valoración como ente titular de derechos más allá de su utilidad para las personas.").

${ }^{43}$ Ct. Const. de Colombia, Nov. 10, 2016, Sent. T-622/16 II 9.30 (p. 138) (“Así las cosas, se trata entonces de establecer un instrumento jurídico que ofrezca a la naturaleza y a sus relaciones con el ser humano una mayor justicia desde el reconocimiento colectivo de nuestra especie como lo sugieren los derechos bioculturales.").

${ }^{44} I d$. at II 9.31 (p. 138). ("En otras palabras, la justicia con la naturaleza debe ser aplicada más allá del escenario humano y debe permitir que la naturaleza pueda ser sujeto de derechos.).

${ }^{45}$ L. 71 (Bol.) (2010).

${ }^{46}$ Id. art. 1 ("La presente Ley tiene por objeto reconocer los derechos de la Madre Tierra, así como las obligaciones y deberes del Estado Plurinacional y de la sociedad para garantizar el respeto de estos derechos."). ${ }^{47}$ Id. art. 2(2) ("El interés de la sociedad, en el marco de los derechos de la Madre Tierra, prevalece . . . en toda actividad humana y por sobre cualquier derecho adquirido.").

${ }^{48} I d$. art. 6 ("Todas las bolivianas y bolivianos, al formar parte de la comunidad de seres que componen la Madre Tierra, ejercen los derechos establecidos en la presente Ley, de forma compatible con sus derechos individuales y colectivos.").

${ }^{49} I d$. ("El ejercicio de los derechos individuales está . . . limitado . . . por el ejercicio de los derechos colectivos en los sistemas de vida de la Madre Tierra, cualquier conflicto entre derechos debe resolverse de manera que no se afecte irreversiblemente la funcionalidad de los sistemas de vida.").

${ }^{50}$ Miglani v. State of Uttarakhand, [Writ Petition (PIL) No.140], MCC 139/2017 at 61 (India) (on file with author).

${ }^{51}$ Id. 
Revista Eletrônica de Direito Processual - REDP.

Rio de Janeiro. Ano 15. Volume 22. Número 3. Setembro a Dezembro de 2021

Periódico Quadrimestral da Pós-Graduação Stricto Sensu em Direito Processual da UERJ

Patrono: José Carlos Barbosa Moreira (in mem.). ISSN 1982-7636. pp. 01-15

www.redp.uerj.br

had to "recognize and bestow" the mentioned motherly essence's constitutionalized guaranties. ${ }^{52}$

Lastly, New Zealand freshly acceded to Maori demands for concession of "personhood" to "a river" and a reserve on the North Island. ${ }^{53}$ Likewise, pleadings federally "filed" in 2017 for trial named the Coloradan riverine organic and inorganic configuration itself as the complainant and sought "to hold" officials "liable for violating" its entitlement to endure, "flourish, . . . be restored, and naturally evolve." ${ }^{54}$ Eventually, however, the lawyer of record withdrew the filing "following a warning from the Colorado Attorney General's Office that it would" requisition "reimbursement of . . . costs." 55

The maximally authoritative institution within the Inter-American human-rights edifice has discerned these trends. ${ }^{56}$ It has commented on them too underscoring:

that the right to a wholesome environment, as an autonomous one and unlike others, protects environmental elements, like woods, rivers, seas, and so forth, as [legally regimented] goods, even in the absence of certainty or self-evidence as to any risk to particular persons. Nature . . . demand[s] safeguard because of not only its usefulness to humans or how [its] degradation might impact [their guaranties], such as that [of] health, life, or personal inviolability, but also [its] significance for other ... organisms, which share the globe and deserve to be intrinsically safeguarded too. ${ }^{57}$

The philosophical tree that unbeknownst to anyone collapses in the middle of the forestland turns into a reality for everyone and into a wielder of rights. ${ }^{58}$

\footnotetext{
${ }^{52} I d$.

${ }^{53}$ Julie Turkewitz, Plaintiff in Federal Lawsuit Over a Violation of Rights Is the Colorado River, N.Y. TIMES, Sept. 27, 2017, at A14 ("In New Zealand, officials declared in March that a river used by the Maori tribe of Whanganui in the North Island to be a legal person that can sue if it is harmed."); Bryant Rousseau, In New Zealand, Rivers and Parks Are People, Too (Legally, at Least), N.Y. TiMES, July 14, 2016, at A11 ("In New Zealand, [a] former national park has been granted personhood, and a river system is expected to receive the same soon. The unusual designations . . came out of agreements between New Zealand's government and Maori groups.").

${ }^{54}$ Julie Turkewitz, Plaintiff in Federal Lawsuit Over a Violation of Rights Is the Colorado River, N.Y. TIMES, Sept. 27, 2017, at A14.

55 Julia Cardi, River of Challenges, L. WK. CoLO., Dec. 12, 2017 (on file with author).

${ }^{56}$ See Environment and Human Rights Opinion, Inter-Am. Ct. H.R., supra note 22, II 62 ("En este sentido, la Corte advierte una tendencia a reconocer personería jurídica y, por ende, derechos a la naturaleza no solo en sentencias judiciales sino incluso en ordenamientos constitucionales.").

57 Id. ("Esta Corte considera importante resaltar que el derecho al medio ambiente sano como derecho autónomo, a diferencia de otros derechos, protege los componentes del medioambiente, tales como bosques, ríos, mares y otros, como intereses jurídicos en sí mismos, aún en ausencia de certeza o evidencia sobre el riesgo a las personas individuales. Se trata de proteger la naturaleza y el medio ambiente no solamente por su conexidad con una utilidad para el ser humano o por los efectos que su degradación podría causar en otros derechos de las personas, como la salud, la vida o la integridad personal, sino por su importancia para los demás organismos vivos con quienes se comparte el planeta, también merecedores de protección en sí mismos.").

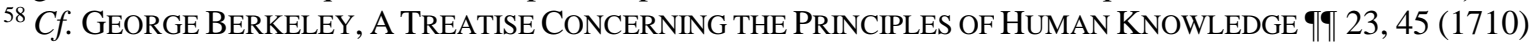
("[T] $[$ here is nothing easier than for me to imagine trees, for instance, in a park . . . and nobody by to perceive
} 
Revista Eletrônica de Direito Processual - REDP.

Rio de Janeiro. Ano 15. Volume 22. Número 3. Setembro a Dezembro de 2021

Periódico Quadrimestral da Pós-Graduação Stricto Sensu em Direito Processual da UERJ

Patrono: José Carlos Barbosa Moreira (in mem.). ISSN 1982-7636. pp. 01-15

www.redp.uerj.br

The analyzed accord itself, in "[n]oting the importance of ensuring the integrity of all ecosystems, including oceans, and the protection of biodiversity," invokes this standpoint. It highlights that these natural forms find acknowledgement in "some cultures as Mother Earth" and, in the next breath, draws attention to "the concept of climate justice" in conjunction with the endeavor "to address" atmospheric alteration. ${ }^{59}$ Hence, the drafters signaled the path from humanitarian to planetary guaranties. They may have been implicitly inviting validation of these by the agencies, associations, or individuals within or without the courtroom; and on various levels: individually, aggregately, societally, humanitarianly, and planetarily (or perhaps universally).

Nominal claimants could proceed not as outsiders but as constituents or agents of the environment or world (or cosmos). Inevitably, they would have to carry the habitually imposed adjective and material burdens. The accused violators could, in fairness, seize every opportunity to defend themselves extrajudicially or judicially, whether procedurally or substantively. At the end of the day, the litigants might be able to solve the controversy sensibly either by negotiating on their own or with the intervention of a trier, an arbitrator, or a mediator. They would have to grapple with all the prospects and challenges of transindividual dispute-resolution as would anyone on the verge or in the midst of complex litigation.

In sum, this reflection catalogued environmental entitlements in the wake of the treaty on greenhouse-gas emissions. It traced the gradation and progression along the notional scale: from individual to earthly entitlements. By endorsing this expansion, while drumming up almost unanimous enthusiasm for the cardinal campaign, the signatories may have scored their biggest, albeit somewhat modest, ${ }^{60}$ success. Most definitely, they will need considerable prodding by the third sector with the support of the judiciary to make any additional headway nationally or internationally. ${ }^{61}$

\footnotetext{
them.") ("The objects of sense exist only when they are perceived; the trees therefore are in the garden . . no longer than while there is somebody by to perceive them.").

${ }^{59}$ Paris Agreement, supra note 3, pmbl..

${ }^{60}$ Cf. Stephen Kim Park, Investors as Regulators: Green Bonds and the Governance Challenges of the Sustainable Finance Revolution, 54 STAN. J. INT'L L. 1, 3 (2018) ("The traditional paradigm of a single comprehensive treaty-based regime, constituted and funded by governments, is arguably defunct.").

${ }^{61}$ Cf. Civil Society, U.N., <http://www.un.org/en/sections/resources-different-audiences/civil-society/> (last visited May 3, 2020) (Home, Resources, Civil Society) (on file with author) ("Civil society is the 'third sector' of society, along with government and business. It comprises civil society organizations and non-governmental organizations.").
} 


\section{REFERENCES:}

African Charter on Human And PeOPles' Rights (Banjul Charter).

Alaska Sport Fishing Ass'n v. Exxon Corp., 34 F.3d 769, 773 (9th Cir. 1994).

Alfred L. Snapp \& Son, Inc., v. Puerto Rico ex rel. Barez, 458 U.S. 592, 602 (1982).

Ángel R. Oquendo, Justice for All: Certifying Global Class Actions, 16 WASH. U. GLOBAL STUD. L. REV. 71, (2017).

ÁNGEL R. OQUENDO, LATIN AMERICAN LAW (2017).

Baatz v. Columbia Gas Transmission, LLC, 814 F. 3d 785, 788 (6th Cir. 2016).

Bernard Williams, Human Rights: The Challenge of Relativism, Lecture at the Raymond \& Beverly Sackler Distinguished Lecture Series 2 (Apr. 23, 1997).

Bryant Rousseau, In New Zealand, Rivers and Parks Are People, Too (Legally, at Least), N.Y. TIMES, July 14, 2016, at A11.

Civil Society, U.N., <http://www.un.org/en/sections/resources-different-audiences/civilsociety/> (last visited May 3, 2020) (Home, Resources, Civil Society) (on file with author).

Const. pmbl. (Bol.) (2009).

CONST. pmbl. (Ecuador) (2008).

Corte Constitucional [Ct. Const.] del Ecuador, July 9, 2015, Sentencia No. 218-15-SEP-CC 9.

Ct. Const. de Colombia, Nov. 10, 2016, Sent. T-622/16.

Digest of Justinian: Liber XLVII. Available at < https://www.thelatinlibrary.com/justinian/digest47.shtml>.

Environment and Human Rights (Arts. 4.1, 5.1, 1.1, and 2 American Convention on Human Rights), Advisory Opinion OC-23/17, Inter-Am. Ct. H.R., (Nov. 15, 2017), available at <http://www.corteidh.or.cr/docs/opiniones/seriea_23_esp.pdf $>$.

Federal Rules of Civil PRocedure.

George Berkeley, A Treatise Concerning the Principles of Human Knowledge IIII 23, 45 (1710).

JUDITH JARVIS THOMSON, THE REALM OF RIGHTS (1990).

Julia Cardi, River of Challenges, L. WK. CoLO., Dec. 12, 2017 (on file with author). 
Revista Eletrônica de Direito Processual - REDP.

Rio de Janeiro. Ano 15. Volume 22. Número 3. Setembro a Dezembro de 2021

Periódico Quadrimestral da Pós-Graduação Stricto Sensu em Direito Processual da UERJ

Patrono: José Carlos Barbosa Moreira (in mem.). ISSN 1982-7636. pp. 01-15

www.redp.uerj.br

Julie Turkewitz, Plaintiff in Federal Lawsuit Over a Violation of Rights Is the Colorado River, N.Y. TIMES, Sept. 27, 2017, at A14.

JÜrgen Habermas, FakTizität und Geltung: BeitRÄGE ZUR DiskURSTHEORIE DES RECHTS UND DES DEMOKRATISCHEN RECHTSSTAATS 311 (1992).

L. 71 (Bol.) (2010).

Letter (676) from Vincent van Gogh to (his brother) Theo van Gogh (Sept. 8, 1888) (on file with author), available at <http://vangoghletters.org/vg/letters/let676/letter.html〉.

Michael D. Shear, Trump Abandoning Global Climate Accord, N.Y. Times, June 2, 2017.

Miglani v. State of Uttarakhand, [Writ Petition (PIL) No.140], MCC 139/2017 at 61 (India) (on file with author).

Org. of Am. States (OAS), Additional Protocol to the American Convention on Human Rights in the Area of Economic, Social, and Cultural Rights, "Protocol of San Salvador," art. 11, Nov. 17, 1988, O.A.S. T.S. No. 69, 1144 U.N.T.S. 123.

Paris Agreement to the United Nations Framework Convention on Climate Change, Dec. 12, 2015, 27 U.N.T.S. 7.d [hereinafter Paris Agreement].

Sierra Club v. Morton, 405 U.S. 727, 741 (1972) (Douglas, J., dissenting).

Stephen Kim Park, Investors as Regulators: Green Bonds and the Governance Challenges of the Sustainable Finance Revolution, 54 StAN. J. INT'L L. 1, 3 (2018).

United States v. Olson, 546 U.S. 43, 45 (2005). 